\title{
Effect of propolis extract on angelfish larval performance and transport
}

\section{Efeito do extrato de própolis no desempenho de larvas e transporte de acará bandeira}

\author{
Douglas da Cruz Mattos ${ }^{1 *}$; Jonas Henrique de Souza Motta ${ }^{1}$; Leonardo Demier \\ Cardoso $^{1}$; João Vitor de Azevedo Manhães ${ }^{1}$; Marcella Costa Radael ${ }^{1}$; \\ João Carlos Fosse Filho'; Samuel Louzada Pereira'; Manuel Vazquez Vidal Júnior ${ }^{2}$
}

\begin{abstract}
This study aimed to evaluate the influence propolis extract inclusion to the feed mixture for juvenile angelfish (Pterophyllum scalare) on larval performance and transport. Levels of propolis extract inclusion consisted of $0,300,600,900$, and $1200 \mathrm{mg} \cdot \mathrm{kg}^{-1}$ of feed. After 14 days of hatching, unmetamorphosed larvae with a total length of $18.4 \mathrm{~mm}$ and $0.11 \mathrm{~g}$ initial weight were used. Six-hundred larvae were divided into 20 experimental units, totalizing 30 larvae each. Experimental units consisted of polythene containers with independent water input and output and a level controller. Each unit was controlled for maintenance of $40 \mathrm{~L}$ water within a recirculation system. After offering feed containing propolis extract, five fish from each experimental unit were packed in bags for transportation only with atmospheric air, without pure oxygen addition. The bags were filled with $300 \mathrm{~mL}$ water on a 2:1 basis of air and water respectively. The total transport time was considered until the death of the third fish in package. At the end of the experiment, data underwent statistical analysis through Statistical Analysis System (SAS, 2001). Results showed there was no significant difference $(\mathrm{P}<0.05)$ neither for any of the studied zootechnical variables (standard length, total length, height, and weight) nor for the transport of juveniles. In conclusion, propolis extract addition to angelfish feed was ineffective for larval performance and for transportation of juveniles, at the levels tested here.
\end{abstract}

Key words: Fish larvae. Larviculture. Ornamental fish.

\section{Resumo}

Este estudo teve como objetivo avaliar a influência da inclusão de extrato de própolis na mistura de ração para juvenis de acará bandeira (Pterophyllum scalare) no desempenho larval e transporte. Os níveis de inclusão de extrato de própolis consistiam em 0, 300, 600, 900 e 1200 mg.kg-1 de alimento. Após 14 dias de incubação, utilizaram-se larvas não metamorfoseadas com um comprimento total de $18,4 \mathrm{~mm}$ e $0,11 \mathrm{~g}$ de peso inicial. Seiscentas larvas foram divididas em 20 unidades experimentais, totalizando 30 larvas cada. As unidades experimentais consistiram em recipientes de polietileno com entrada e saída independentes de água e um controlador de nível. Cada unidade foi controlada mantendo-se o volume de $40 \mathrm{~L}$ de água, compondo um sistema de recirculação. Após a oferta de alimento contendo extrato de própolis, cinco peixes de cada unidade experimental foram acondicionados em sacos para transporte

\footnotetext{
${ }^{1}$ Discentes de Pós-graduação, Universidade Estadual do Norte Fluminense Darcy Ribeiro, UENF/CCTA/LZO, Centro de Ciências e Tecnologias Agropecuárias, Laboratório de Zootecnia, Campos dos Goytacazes, RJ, Brasil. E-mail: douglas_uenf@yahoo. com.br; Motta.henri@gmail.com; leonardodemier@hotmail.com; joao.v.m@hotmail.com; marcellaradael@yahoo.com.br; joão. fosse@hotmail.com; samuel_lp@hotmail.com

2 Prof. Adjunto Titular, UENF/CCTA/LZO, Centro de Ciências e Tecnologias Agropecuárias, Laboratório de Zootecnia, Campos dos Goytacazes, RJ, Brasil. E-mail: mvidal@uenf.br

* Author for correspondence
} 
somente com ar atmosférico, sem adição de oxigênio puro. Os sacos foram cheios com $300 \mathrm{ml}$ de água na proporção 2:1 de ar e água, respectivamente. O tempo total de transporte foi considerado até a morte do terceiro peixe na embalagem. No final do experimento, os dados foram submetidos à análise estatística através do Statistical Analysis System (SAS, 2001). Os resultados mostraram que não houve diferença significativa $(\mathrm{P}<0,05)$ nem para nenhuma das variáveis zootécnicas estudadas (comprimento padrão, comprimento total, altura e peso) nem para o transporte de juvenis. Em conclusão, a adição de extrato de própolis para a alimentação de acará bandeira foi ineficaz para o desempenho larval e para o transporte de juvenis, nos níveis aqui testados.

Palavras-chave: Larvas de peixe. Larvicultura. Peixe ornamental.

\section{Introduction}

Pterophyllum scalare is a species of cichlid belonging to the Perciformes order and Actinopterygii class. Anatomically, it has a laterally compressed body with elongated dorsal and anal fins, giving a triangular appearance to the fish. It also has a thin and long ventral fin; and in the wild standard, it has a predominant silver color that contrasts with its black vertical lines (CACHO et al., 1999). This species is native from the Amazon Basin and inhabits preferably shallow and calm waters, among roots and leaves of aquatic vegetation (FERRAZ, 1999). In nature, it feeds on invertebrates, thus being considered a carnivore (DEGANI, 1993).

Propolis is a natural product composed of a series of resinous substances, which is gummy and balsamic with viscous consistency; its color may vary from green-yellow to dark brown or reddish. Propolis chemical composition varies with plant source visited by bees, being composed of 45 to $55 \%$ resins and balsams, 7.55 to $35 \%$ wax, 5 to $10 \%$ volatile oils, $5 \%$ pollen, $5 \%$ diverse organic materials and minerals (CUNHA, 2004). It is made up of more than 200 compounds, including flavonoids (pinocembrin; galangin; caffeic, ferulic, propolone, and nemorosone acids; and methyl derivatives; guttiferone; coumaric acid; phenolic acids), aliphatic acids, aromatic acids, esters, di- and triterpenes, pollen, sugars, and minerals (KHALIL, 2006; ORSOLIC; BASIC, 2003; CUNHA, 2004).

Propolis has been shown to be effective on stimulation of non-specific immune response, against gram-positive bacteria, gram-negative and fungi, and can act as growth promoter increasing weight gain of animals (SANCHEZ; GALARDI, 1989; FERNANDES JUNIOR et al., 1997; GUNATHILAKA et al., 2015).

Several studies have been conducted to test fish resistance to stress, in order to evaluate fish production quality at different stages, justifying the use of certain additives such as propolis. Stress can inducted by exposure to air (LUZ; PORTELLA, 2005), to pathogenic bacteria (GATESOUPE, 1995) and acute exposure to different physical-chemical water variables (MAZIK et al., 1987, VAN ANHOLT et al., 2004).

Transport is a critical process in the fish productive chain. Management during this step can result in physiological changes which can influence the perfect functioning of the body, causing stress (URBINATI; CARNEIRO, 2004; ADAMANTE, 2005). Combined with these characteristics, densification, exposure to poor-quality water and intense fish motor activity may result in weakened fish after transport, contributing to higher death rates.

Thus, we aimed in this study to investigate the effects of different propolis extract concentrations on larval performance of angelfish kept in a recirculation system; later, as stress causing agent and challenging task, fish was submitted to transport.

\section{Material and Methods}

The experiment was carried out in the aquaculture sector of the Animal Science Laboratory, Universidade Estadual do Norte Fluminense Darcy Ribeiro -UENF (State University of Northern Rio de Janeiro - UENF), during the second semester of 2014. 
Angelfish juveniles used in this study were obtained from breeding of broodstocks belonging to the aquaculture sector of the UENF. Sixhundred same-age juveniles were divided into 20 experimental units. After 14 days hatching, unmetamorphosed larvae (elongated body, no pigmentation, and short fins) were selected with a total length of $18.4 \pm 0.67 \mathrm{~mm}$ and $0.11 \pm 0.84 \mathrm{~g}$ initial weight. The experimental units consisted of polythene containers with independent water input and output and a level controller. Each unit was controlled for maintenance of $40 \mathrm{~L}$ of water.

The study was composed of five treatments with four replicates each, totaling 20 experimental units. Treatments consisted of propolis extract concentrations (T1- 0, T2- 300, T3- 600, T4- 900, $\mathrm{T} 5-1200 \mathrm{mg} \cdot \mathrm{kg}^{-1}$ propolis inclusion).

Regarding feeding frequency, treatments received the same amount of food three times a day (8 a.m., 2 p.m., and 5 p.m.). The supplied amount was offered ad libtum; however, feed remains were avoided.

Propolis inclusion into the feed was made by spraying, adding a commercial product containing $30 \%$ crude propolis diluted in $70 \%$ of grain alcohol. After added, solution was homogenized so that all received the solution uniformly. After spraying, treatments were exposed to the environment naturally for volatilization of alcohol, which served as a vehicle for the propolis extract.

Feed offered in the treatments had isoproteic characteristics, with $36 \%$ crude protein, and variation only for propolis extract inclusion level. Composition percentage of ingredients in the feed base can be seen in Table 1 .

Experiments were carried out in a water recirculation system (WRS) with $1.8 \mathrm{~m}^{3}$ water, where the same water was used in all experimental units. To this system was applied a filtering system composed of two mechanical and biological filters. After passing through these filters, water was released into two interconnected return boxes, from which it was pumped back to the experimental units. A fraction of 30L of water was siphoned daily for removal of feed leftovers and feces. After handling, clean water was added to the system. The experimental period was lasted 33 days.

At the end, a significant sample of ten fish of each replicate was measured and weighed for performance evaluation, assessing the following variables: total length (TL) standard length (SL) and height $(\mathrm{H})$, with the aid of a digital pachymeter, weight (W) and survival (S) with the aid of a precision scale with four decimal places.

Biometric results were also used for calculation of some parameters such as specific growth rate, $\mathrm{SGR}=100 \times$ (average final weight - average initial weight)/ time (day).

For transport impact analysis, five fish of each replicate were added to plastic bags for shipping. In each transport, $300 \mathrm{ml}$ water was added to the packages, being used at a ratio of 2:1 air-water, without supplemental oxygen. The packages were analyzed every 4 hours by counting fish death. When the last fish died within a bag, transport time was considered finished, being subsequently used for statistical analysis.

Water physical and chemical parameters, such as dissolved oxygen, $\mathrm{pH}$, and temperature, were evaluated periodically to maintain them within the recommended ranges for this species.

In order to assess the fish resistance to transport stress, after the trial period, five fish from each experimental unit were packed into bags to being transported only with atmospheric air, without pure oxygen, at a 2:1 air/water ration in a water volume of $300 \mathrm{~mL}$. The maximum transport time lasted until the death of the third fish in a bag. The bags were stored in plastic boxes, being handled manually every 3 hours. These samples were kept in a wellventilated place protected from the sun.

As for the statistics, we adopted a completely randomized design for both experiments (performance and transport). The statistical analyses were performed using the statistical package Statistical Analysis System (SAS, 2001). 
Table 1. Composition, guarantee levels of experimental feed and inclusion of propolis extract.

\begin{tabular}{ll}
\hline \multicolumn{1}{c}{ GUARANTEE LEVELS } & Kg \\
\hline Crude Protein (min) & $360 \mathrm{~g}$ \\
Ether Extract (min) & $70 \mathrm{~g}$ \\
Crude Fiber (max) & $60 \mathrm{~g}$ \\
Mineral Matter (max) & $130 \mathrm{~g}$ \\
Moisture (max) & $120 \mathrm{~g}$ \\
Calcium (max) & $35 \mathrm{~g}$ \\
Phosphorous (min) & $10 \mathrm{~g}$ \\
Folic Acid (min) & $10 \mathrm{mg}$ \\
Pantothenic Acid (min) & $80 \mathrm{mg}$ \\
Choline (min) & $2000 \mathrm{mg}$ \\
Inositol (min) & $300 \mathrm{mg}$ \\
Copper (min) & $10 \mathrm{mg}$ \\
Iron (min) & $50 \mathrm{mg}$ \\
Iodine (min) & $3 \mathrm{mg}$ \\
Manganese (min) & $80 \mathrm{mg}$ \\
Selenium (min) & $0,45 \mathrm{mg}$ \\
Zinc (min) & $200 \mathrm{mg}$ \\
Vitamin A (min) & $15000 \mathrm{UI}$ \\
Vitamin D3 (min) & $4000 \mathrm{UI}$ \\
Vitamin B6 (pyridoxine) (min) & $20 \mathrm{mg}$ \\
Vitamin C (min) & $450 \mathrm{mg}$ \\
Vitamin PP (min) & $120 \mathrm{mg}$ \\
Vitamin B1 (thiamine) (min) & $20 \mathrm{mg}$ \\
Vitamin B2 (riboflavin) (min) & $30 \mathrm{mg}$ \\
Vitamin B12 (min) & $10 \mathrm{mcg}$ \\
Vitamin E (min) & $150 \mathrm{UI}$ \\
Propolis Extract & $0 / 300 / 900 / 1.200 \mathrm{mg}$ \\
\hline
\end{tabular}

\section{Results and Discussion}

During the trial period, water temperature was $27.3 \pm 1.13 \mathrm{C}$, being considered within the comfort range for this species according to Froese, R. and Pauly, D. (2016). The average level of dissolved oxygen was $5.91 \pm 0.91 \mathrm{mg} \mathrm{L}^{-1}$, $\mathrm{pH}$ values averaged $7.22 \pm 0.87$, which are satisfactory for the species.

Regarding the assessed zootechnical variables (standard length, total length, height, and weight), the highest averages were observed for control and for treatments with the highest level of propolis inclusion. On the other side, the lowest averages were observed for treatment with the lowest level of propolis inclusion. After performance of statistical analyses, we found no significant difference $(P>0.05)$ for any of the evaluated variables for any of the treatments.

On average, survival rates showed different results whether compared to standard length, total length, height, and weight. The highest averages were observed for treatments with 600, 1200 and $0 \mathrm{mg} \cdot \mathrm{kg}^{-1}$, respectively; yet the lowest average was observed by inclusion of $300 \mathrm{mg}$ propolis. Most of the deaths during the experimental period occurred within the initial phase (first five days). Moreover, the deaths were accounted for treatments in which there was propolis extract inclusion. Table 2 shows the averages for the mentioned variables along with their standard error. 
Table 2. Average values and standard error (SE) of the average for variables of Standard length in mm (SL), Total length in $\mathrm{mm}(\mathrm{TL})$, height in $\mathrm{mm}(\mathrm{H})$, weight $(\mathrm{W})$ in $\operatorname{grams}(\mathrm{W})$ and survival $(\mathrm{S})$ in percentage.

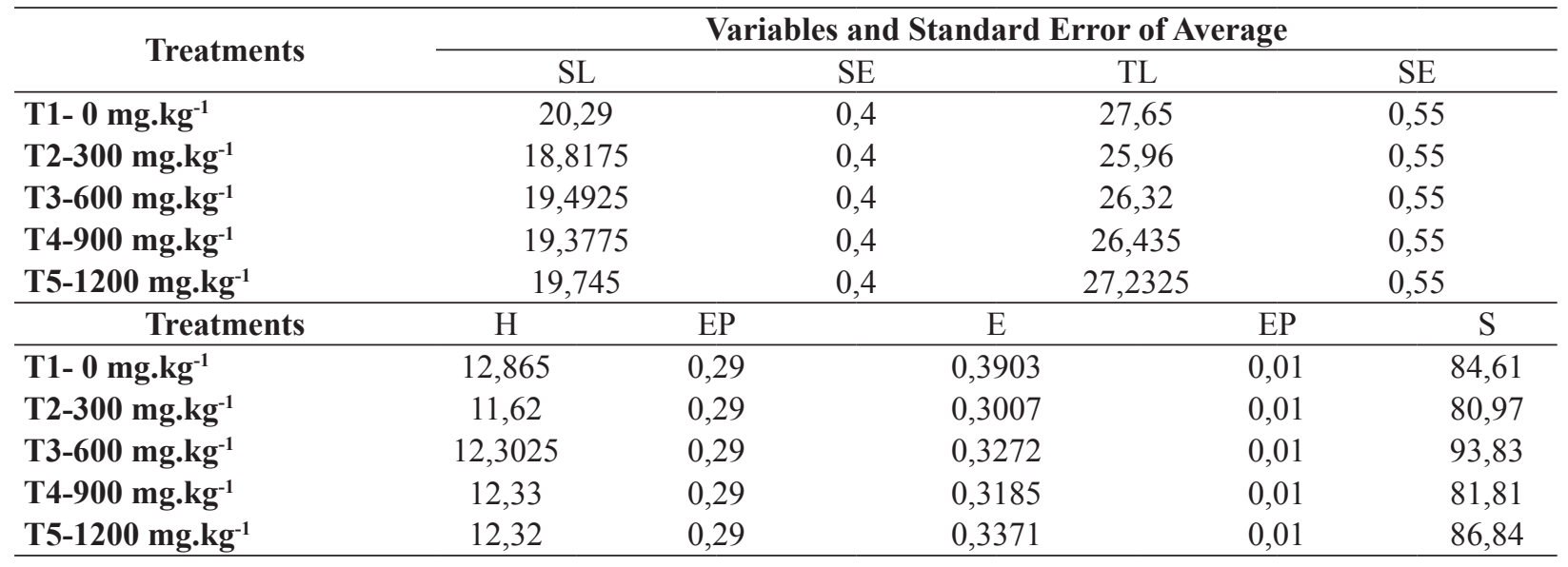

Table 2- Average values and standard error of the average for variables of Standard length in $\mathrm{mm}$ (SL), Total length in $\mathrm{mm}(\mathrm{TL})$, height in $\mathrm{mm}(\mathrm{H})$, weight(W) in grams(W) and survival rate (S) in percentage.

Results for length and weight growth rates were similar, being the largest averages observed for treatments with 0 and $1.200 \mathrm{mg} \cdot \mathrm{kg}^{-1}$, respectively. Meanwhile, the lowest average was recorded for the treatment with $300 \mathrm{mg} \cdot \mathrm{kg}^{-1}$. As previously mentioned, there was no significant difference $(\mathrm{P}>0.05)$ between the different growth rates. Figure
1 and 2 display the obtained values and confidence intervals for the growth rates.

At the end of the experimental period, the fish transport results followed the same patterns for the zootechnical variables, without significant differences $(\mathrm{P}>0.05)$ among treatments.

The highest averages were observed for treatments with $600 \mathrm{mg}$, lasting 89 hours of transportation. The treatments receiving 0,1200 , 300 , and $900 \mathrm{mg}$ of propolis lasted for $85,80,77,76$, and 25 hours in transport. Figure 3 highlights the differences among treatments.

Figure 1. Values observed for rate of growth in lenght (Centimeters).

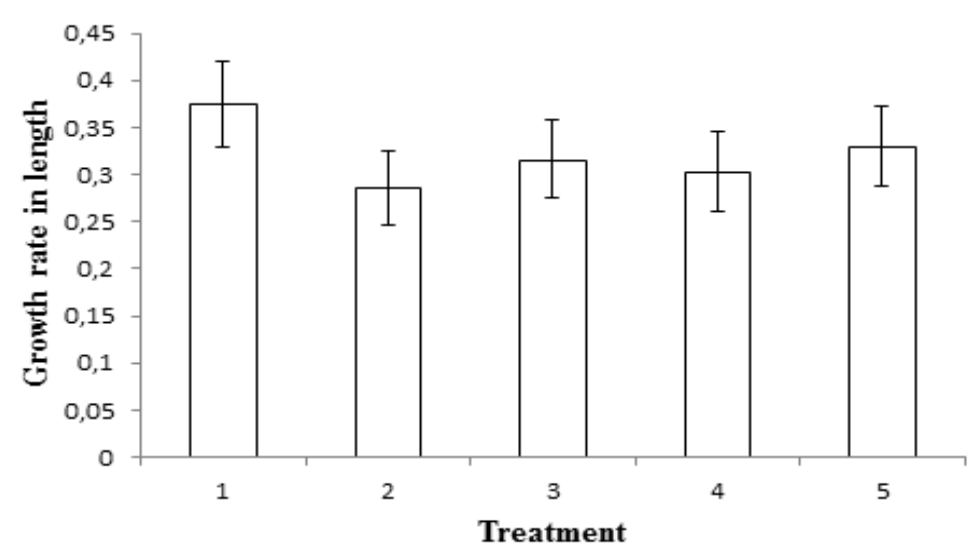


Figura 2. Values observed presented for growth rate in weight.

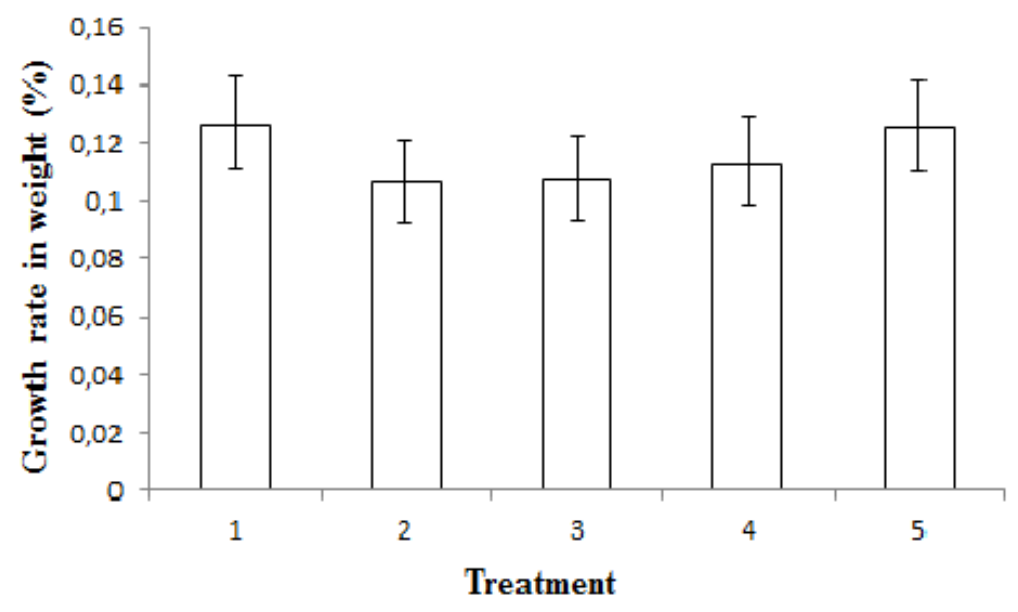

Figure 3. Change in hours of transport at the different treatments and their respective confidence intervals.

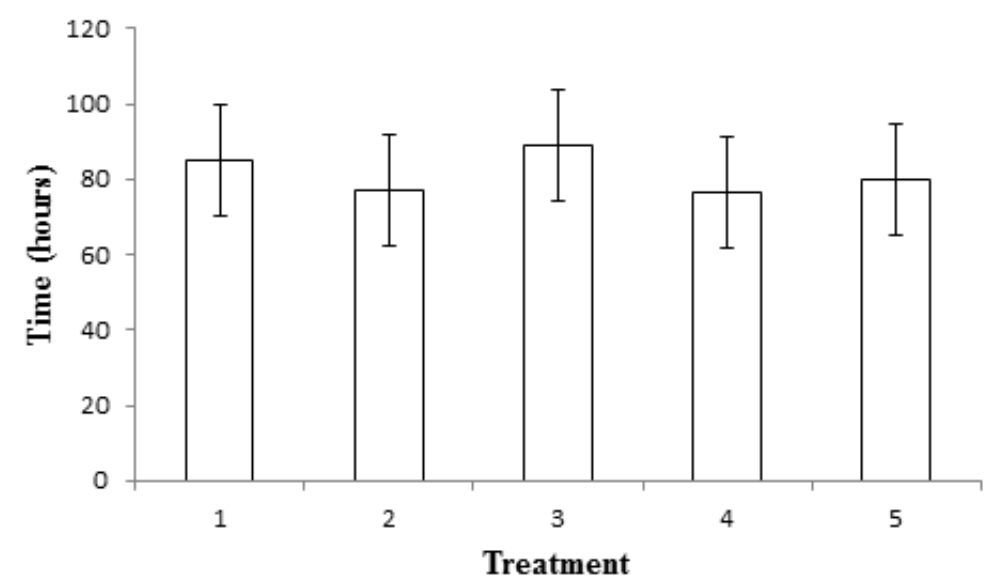

The findings encountered here were similar to those reported by different authors. Santos et al. (2013), testing doses between 0 and $1.50 \%$ of residue inclusion, found no positive effects on the performance of tilapia (Oreochromis niloticus). Kashkooli et al. (2011) reported that propolis had no effect on growth and blood parameters such as levels of plasma protein, albumin, HDL cholesterol, LDL cholesterol, and triglycerides of Oncorhynchus mykiss.

Although this study presented no significant differences for the analyzed variables, several other authors have been successful in tests with propolis inclusion in animal feed, for weight gain, growth, and resistance to pathogens. Propolis extract inclusion was efficient regarding weight gain and feed conversion in Oreochromis niloticus (ABD-EL-RHMAN, 2009). Also, Meurer et al. (2009) observed that tilapias succeeded in growth performance if supplemented with brown propolis extract. Agostinho (2010) study found that propolis inclusion could improve pacu (Piaractus mesopotamicus) weight gain when fed at a frequency of 3 times a day.

The use of propolis ethanolic extract had significant effect on rainbow trout, acting as growth promoter, hepatoprotective and immunostimulant (DENG et al., 2011). Adding propolis extract to 
the diet of Myxocyprinus asiaticus improved the non-specific immune response of this fish, besides reducing in $35 \%$ mortality when infected with Aeromonas hydrophila, compared to the treatment without propolis addition (ZHANG et al., 2009).

Propolis seems to have beneficial effects on fish due to an antimicrobial activity. In this extract, there are numerous substances such as flavonoids, aromatic acids, and esters (BURDOCK, 1998). These compounds have antimicrobial action resulting in an intestinal composition enhancement, thus, improving digestion and absorption of nutrients (KUJUMGIEV et al., 1999).

The highest concentration leading to fish death, during the trial, was observed right at the start of the study, mainly in treatments with propolis extract inclusion into the diet. This result can be explained by changes in feed palatability, making it less attractive to fish.

A few studies suggest that the inclusion of propolis in diet may contribute to decline in consumption and, consequently, reducing growth performance. Waffa et al. (2014), studying tilapias (Oreochromis niloticus) noted a significant reduction in feed consumption for treatments containing propolis when compared to the control; however, the same authors found no difference in survival rates for treatment with propolis extract compared to the control.

Fish transport is a key step in the productive chain and requires special care in order to reduce losses by death. This process may cause acute stress in fish, both of behavioral and physiological orders (URBINATI; CARNEIRO, 2004). All handling process since capture and accommodation at high density until further reallocation at high-density packaging for transport together with the interactions among fish can act as stressors (ADAMS, 1990).

During transport, fish may suffer various injuries that would result in loss of scales and mucus, paving the way for infections by bacteria and fungi (MOYLE; CECH JUNIOR, 1998). According to
Kubitza (2004), high densities can lead to rapid deterioration of the aquatic environment from an excess of organic matter, phosphorous, and nitrogen, favoring the development of pathogenic microorganisms.

Upon all the above features related to the transport, it is justified its use as parameter in evaluating the effectiveness of propolis. However, our results showed no significant difference. Such outcome can be explained by the short period of transport. The high density and non-use of pure oxygen in fish packaging may have contributed to fast fish death, and possibly masking the effect of propolis extract.

The lack of efficacy of propolis extract on angelfish performance might have been due to the influence of factors such as different substance patterns in each commercial product used in the experiment since propolis produced in Brazil varies in its constituents as shown by Castro et al. (2007). These authors concluded that propolis composition varies with the time of year at which it is collected.

Many of beneficial effects of propolis have been reported such as antimicrobial, antifungal, anti-inflammatory actions that have a secondary influence on fish performance. Nevertheless, fish used here had no influence or were submitted to adverse situations where such influence of propolis was less effective, during the experimental period. This fact may have contributed to the non-occurrence of significant differences for the variables analyzed.

The levels of propolis extract inclusion evaluated in this experiment were not able to affect the performance of larval parameters, as well as had no benefit for angelfish transport (Pterophyllum scalare).

\section{Acknowledgments}

To CAPES and Universidade Estadual do Norte Fluminense Darcy Ribeiro, for the financial and structural assistance to carry out the study. 


\section{Reference}

ABD-EL-RHMAN, A. M. M. Antagonism of Aeromonas hydrophila by propolis and its effect on the performance of Nile tilapia, Oreochromis niloticus. Fish Shellfish Immunology, London, v. 27, n. 3, p. 454-459, 2009.

ADAMANTE, W. B. Estresse de alevinos de dourado e mandi sob diferentes densidades e tempos de transporte. 2005. Dissertação (Mestrado em Aquicultura) Universidade Federal de Santa Catarina, Florianópolis.

ADAMS, S. Status and use of biological indicators for evaluating the effects of stress on fish. In: ADAMS, S. M. (Ed.). Biological indicators of stress in fish. Bethesda: American Fisheries Society, 1990. p. 1-8.

AGOSTINHO, L. M. Própolis no desempenho produtivo de juvenis de pacu criados em tanque rede e arraçoados com baixa e alta frequência alimentar. 2010. Dissertação (Mestrado) - Universidade Estadual Paulista, Faculdade de Medicina Veterinária e Zootecnia de Botucatu, Botucatu.

BURDOCK, G. A. Review of the biological properties and toxicity of bee propolis (propolis). Food and Chemical Toxicology, Oxforf, v. 36, n 4, p. 347-363, 1998.

CACHO, M. S. R. F.; YAMAMOTO, M. E.; CHELLAPPA, S. Comportamento reprodutivo do acará bandeira, Pterophyllum scalare cuvier e valenciennes (Osteichthyes, Cichlidae). Revista Brasileira de Zoologia, Curitiba, v. 16, n. 1, p. 653-664, 1999.

CASTRO, M. L.; CURY, J. A.; ROSALEN, P. L.; ALENCAR, S. M.; DUARTE, M. I. S.; KOO, H. Própolis do sudeste e nordeste do Brasil: influência da sazonalidade na atividade antibacteriana e composição fenólica. Química Nova, São Paulo, v. 30, n. 7, p. 15121516, 2007.

CUNHA, F. M. Caffeic acid derivatives: in vitro and in vivo anti-inflammatory properties. Free Radical Research, London, v. 38, n. 11, p. 1241-1253, 2004.

DEGANI, G. Growth and body composition of juveniles of Pterophyllum scalare (Lichtenstein) (Pisces; Cichlidae) at differents densities and diets. Aquaculture and Fisheries Management, Oxford, v. 24, n. 6, p. 725730, 1993.

DENG, J.; AN, Q.; BI, B.; WANG, Q.; KONG, L.; TAO, L.; ZHANG, X. Effect of ethanolic extract of propolis on growth performance and plasma biochemical parameters of rainbow trout (Oncorhynchus mykiss). Fish Physiology. Biochemistry, Amsterdam, v. 37, n. 4, p. 959-967, 2011.
FERNANDES JUNIOR, A.; LOPES, C. A. M.; SFORCIN, J. M.; FUNARI, S. R. C. Population analysis of susceptibility to propolis in reference strains of Staphylococcus aureus and Escherichia coli. Journal of Venomous Animals and Toxins Including Tropical Disease, São Paulo, v. 3, n. 2, p. 287-294, 1997.

FERRAZ, E. Management and diseases of the ornamental fish exported from the Rio Negro basin. In: VAL, A. L.; VAL, V. M. F. A. Biology of tropical fishes. Manaus: INPA, 1999. p. 99-111.

FROESE, R.; PAULY, D. FISHBASE. Eletronic publication. [S.1.: s.n.], 2016. Available at: $<\mathrm{http}: / / \mathrm{www}$. fishbase.org/Summary/SpeciesSummary.php?ID=4717 \&AT $=$ acar\%C3\%A1+bandeira $>$. Access at: 09 ago 2017.

GATESOUPE, F. J. A method for the early assessment of the quality of turbot larvae. Aquaculture International, Dordrecht, v. 3, n. 3, p. 150-154, 1995.

GUNATHILAKA， G. L. B. E.; YONG-KAP, H.; SE-JIN, L.; KYEONG-JUNG, L. Effects of dietary supplementation of two types of propolis on growth performance, feed utilization, innate immunity and disease resistance of olive flounder Paralichthys olivaceus. Fisheries and Aquatic Sciences, London, v. 18, n. 4, p. 367-372, 2015.

KASHKOOLI, O. B.; DORCHEH, E. E.; MAHBOOBISOOFIANI, N.; KASHKOOLI, A. S. Long-term effects of propolis on serum biochemical parameters of rainbow trout (Oncorhynchus mykiss). Ecotoxicology and Environmental Safety, Amsterdam, v. 74, n. 3, p. 315318, 2011.

KHALIL, M. L. Biological activity of bee propolis in health and disease. Asian Pacific Journal of Cancer Prevention, BangKok, v. 7, n. 1, p. 22-31, 2006.

KUBITZA, F.; KUBITZA, L. M. M. Principais parasitoses dos peixes cultivados. 4. ed. Jundiaí: [s.n.], 2004. $108 \mathrm{p}$.

KUJUMGIEV, A.; TSVETKOVA, I.; SERKEDJIEVA, Y.; BANKOVA, V.; CHRISTOV, R.; POPOV, S. Antibacterial, antifungal and antiviral activity of propolis of different geographic origin. Journal of Ethnopharmacoly, Lausanne, v. 64, n. 3, p. 235-240, 1999.

LUZ, R. K.; PORTELLA, M. C. Frequência alimentar na Larvicultura de trairão (Hoplias lacerdae). Revista Brasileira de Zootecnia, Viçosa, MG, v. 34, n. 5, p. 14421448, 2005. 
MAZIK, P. M.; BRANDT, T. M.; TOMASSO, J. R. Effects of dietary vitamin $\mathrm{C}$ on growth, caudal fin development, and tolerance of aquaculture-related stressors in Channel catfish. Progressive Fish-Culturist, Washington, v. 49, n. 1, p. 13-16, 1987.

MEURER, F.; COSTA, M. M.; BARROS, D. A. D.; OLIVEIRA, S. T. L.; PAIXÃO, P. S. Brown propolis extract in feed as a growth promoter of Nile tilapia (Oreochromis niloticus,) fingerlings. Aquaculture Research, Danvers, v. 40, n. 5, p. 603-608, 2009.

MOYLE, P. B.; CECH JUNIOR, J. J. Fishes: an introduction to ichthyology. $2^{\text {th }}$ ed. Englewood Cliffs: Prentice Hall, 1998. 559 p.

ORSOLIC, N.; BASIC, I. Immunomodulation by watersoluble derivative of propolis: a factor of antitumor reactivity. Journal. Ethnopharmacology, Lausanne, v. 84, n. 2, p. 265-273, 2003.

SANCHEZ, M.; GALARDI, R. Influencia del propoleo en la convercion de lechones destetados. In: SIMPOSIO SOBRE LOS EFECTOS DEL PROPOLEO EN LA SALUD HUMANA Y ANIMAL CONSEJO CIENTÍFICO DEL INSTITUTO DE MEDICINA VETERINARIA,1., 1989, Varadero, Matanzas. Memorias... Varadero, Matanzas: [s.n.], 1989. p. 211214.
SANTOS, E. L.; SILVA, F. C. B. da; PONTES, E. C.; LIRA, R. C.; CAVAlCANTE, M. C. A. Resíduo do processamento do extrato de própolis vermelha em ração comercial para alevinos de tilápia do Nilo (Oreochromis niloticus). Comunicata Scientiae, v. 4, n. 2, p. 179-185, 2013.

URBINATI, E. C.; CARNEIRO, P. C. F. Práticas de manejo e estresse dos peixes em piscicultura. In: CYRINO, E. J. P. (Ed.). Tópicos especiais de piscicultura de água doce tropical intensiva. São Paulo: Editora Tecart, 2004. cap. 6, p. 171-94.

VAN ANHOLT, R. D.; KOVEN, W. M.; LUTZKY, S.; BONGA, S. E. W. Dietary supplementation arachidonic acid alters the stress response of gilthead seabream (Sparus aurata) larvae. Aquaculture, Amsterdam, v. 238, n 1-4, p. 369-383, 2004.

WAFFA, E.; DOAA, I.; El-MURR, A.; RANIA, M. Effects of dietary inclusion of black cumin seeds, green tea and propolis extraction growth parameters, body composition and economic efficiency of Nile Tilapia, Oreochromis niloticus. World Journal of Fish and Marine Science, Dubai, v. 6, n. 5, p. 447-452, 2014.

ZHANG, G. S.; YU, D.; YUAN, H. Propolis and Herba Epimedii extracts enhance the non-specific immune response and disease resistance of Chine sesucker, Myxocyprinus asiaticus. Fish Shellfish Immunology, London, v. 26, n. 3, p. 467-472, 2009. 
